\title{
Corporate Greening and Changing Regulatory Regimes: the UK Water Industry
}

\author{
Anja Schaefer* \\ Open University, Milton Keynes, UK
}

\begin{abstract}
This article looks at the relationship between economic regulation, environmental regulation, company strategy and the environment in the UK water and sewerage industry. The regulatory field in this industry, following privatization in 1989, is highly complex and interdependent. The paper presents three case studies of company interpretation of and response to changes in this regulatory field, focusing particularly on the third review by the economic regulator, in 1999, which involved a reduction of the prices companies were allowed to charge their customers. This had significant but complex repercussions for environmental strategy and management in the companies, with different impacts on mandatory and nonmandatory activities. It also showed in relief the opportunities for building coalitions between companies and the environmental regulator, both in general terms and revolving around specific, local environmental issues and schemes. Companies' strategic direction was also found to have an impact on their response to the regulatory review. Copyright (C) 2007 John Wiley \& Sons, Ltd and ERP Environment.
\end{abstract}

Received 14 June 2006; revised 20 May 2007; accepted 13 June 2007

Keywords: corporate greening; environmental management; economic regulation; water industry; United Kingdom

\section{Introduction}

T

HIS PAPER AIMS TO PROVIDE INSIGHTS INTO THE WAY IN WHICH COMPANIES RESPOND TO AND INTERACT with the regulatory field and how non-environmental types of regulation impact on corporate environmental management. This will further our understanding of the mechanisms that guide corporate greening and how corporate environmental management can be promoted.

Corporate greening is intricately linked with regulation (Hunt and Raman, 2000; Schaefer and Harvey, 2000), and pre-empting or early adaptation to further regulatory measures is often given as one reason for a pro-active environmental management approach (see, e.g., Roome, I992; Hunt and Auster, I990; Stead and Stead, I996). While the bulk of work on regulation and greening has focused on the impact of environmental regulation, other types of regulation also interface with corporate environmental management, although their impact has received much less attention. This paper aims to address this gap in the literature.

Economic regulation is a common feature in many industries, particularly those that affect the public good significantly, such as utilities. It impacts on most aspects of company strategy and management, including environmental strategy and management, in industry sectors that are subject to it. Although there is a sizeable

* Correspondence to: Anja Schaefer, Open University Business School, Michael Young Building, Walton Hall, Milton Keynes MK7 6AA, UK. E-mail: a.schaefer@open.ac.uk 
literature on economic regulation of utilities in general, little of this literature looks directly at environmental impacts of that regulation, despite the fact that some industry regulators, such as the Office of Water Services in the UK (OFWAT), have an explicit duty to consider the environmental sustainability of the industry.

This paper studies how particular changes in economic regulation have affected the environmental strategy and management of individual companies in the UK water and sewerage industry. It aims to contribute to our understanding of the interaction between non-environmental and environmental regulation, as well as between wider corporate (environmental) strategy and regulation, in influencing corporate greening.

The following research questions are addressed.

- How do companies respond to changes in economic regulation in terms of their environmental strategy and management?

- To what extent and how does environmental regulation interact with this impact?

- What, if any, is the mediating role of companies' wider environmental strategy and particularly their views on the relationship between environmental and economic performance?

- To what extent and how do companies act strategically to reconcile environmental and economic regulatory pressures?

\section{Environmental Regulation, Economic Factors and Environmental Performance}

Firms' environmental management efforts are known to be influenced by environmental regulation. A number of studies have shown that corporate environmental management is strongly influenced by regulation and that companies tend to define their environmental responsibilities in terms of what environmental issues are regulated in their industry (Hunt and Raman, 2000; Schaefer and Harvey, 2000). While self-regulatory schemes of industries exist and have been shown to work to some extent and under some circumstances, they do not seem to work under all circumstances and often need the threat of regulation as a starting point or fall-back (see, e.g., Smith, I996; Eden, I997; Maltby, I997).

There is a relatively long-standing debate on the relationship between environmental regulation and firms' economic performance (Wubben, I999; Jaffe et al., I995). Contrary to some views that imposition of stricter environmental regulation will be to the detriment of the economic performance of firms subject to it and may thus lead to lower national productivity and removal of industrial activity to countries with lower environmental standards (Low and Yeats, I992), others argue that environmental regulation can stimulate technological and institutional innovation, thus making firms subject to it more competitive (Porter and van der Linde, I995; Pickman, I998; King, 2000). Some more recent research, however, suggests that environmental regulation does not automatically lead to radical innovation (Smith and Crotty, 2006) or short term improvements to firms' competitiveness (Wubben, I999).

While there has been much consideration given to the question of whether environmental regulation impacts on economic performance of a firm, less attention has been given to the question of whether changes in a firm's economic situation (for instance through economic regulation) may also have an impact on its environmental performance. If compliance with environmental standards and improved environmental management in general have a negative impact on economic performance, we might expect that under circumstances of reduced income firms would opt to cut environment related expenses. If, however, there is a positive or neutral relationship between good environmental management and financial performance, a reduction of income may not lead to a reduction of environmental investment.

The direction of influence between environmental and economic performance may be difficult to determine with certainty. Extensive research into the relationship between social performance in general and economic performance has been inconclusive (Margolis and Walsh, 2003; McWilliams and Siegel, 2000). While there is no evidence that good social performance would harm economic performance, moderate evidence for a positive relationship between the two (Pava and Krausz, I996) is difficult to interpret. It could be that firms that show good social performance do indeed derive a competitive advantage from it but it could equally be that only financially successful firms feel able to invest money into efforts directed at social performance (Crane and Matten, 2004). 
The question is therefore not so much one of a proven relationship but what firms believe to be the case. Firms that believe in a negative relationship between environmental investment and financial performance may cut back on the former if the latter is threatened. On the other hand, firms that believe in a positive (or at least neutral) relationship between the two parameters may not cut back on environmental investment in the face of tighter financial circumstances, or might even increase this investment.

This then becomes - at least partly - a question of strategic outlook of the firm. Firms that have built their strategic direction at least partly around a good environmental reputation are more likely to perceive a positive relationship between environmental investment and financial performance and may not cut back on the former if economic circumstances become tighter. This would be in line with previous research that showed that firms' response to environmental regulation was guided by their strategic outlook (Søgaard and Madsen, 2005; Rugman and Verbeke, 2000).

Regulation is best not regarded as a static given to which firms react, but is often flexibly enacted in day-to-day encounters between business managers and environmental regulators and subject to varying circumstances (Fineman, I998; Fineman and Sturdy, 1999). Firms' response to regulation may also result in co-operative and collaborative behaviour, depending on the institutional and economic context (Harrison and Easton, 2002).

\section{The Regulatory Regime of the UK Water Industry}

The UK water industry was privatized in I989 as part of a larger privatization programme of public utilities, aiming to make these industries more efficient by opening them up to competition and exposing them to the profit motive. Privatization was also intended as a means to inject new money into the industry in order to counter decades of under-investment and enable it to comply with European environmental legislation (Bakker, 2003; Maloney, 200I; Thatcher, 1998).

At privatization a new, complex regulatory regime was set up. Companies operate under a licence to provide defined services. An independent industry regulator was set up to prevent monopoly abuse by controlling prices while ensuring companies earn at least a normal profit (Parker, I997). The water industry regulator (the Office of Water Services, OFWAT) regulates restrictions on charging, customer interface, levels of service and service targets among others. OFWAT sets prices that companies can charge to consumers based on the rate of inflation plus a so-called ' $K$ ' factor, where $K$ can be positive - to allow for capital investment - or negative - to pass on efficiency savings to consumers. By making efficiency savings over and above those envisaged in the setting of the $K$ factor, companies can make profits for their shareholders. The price formula is now negotiated every five years (Bakker, 2003). In the first two reviews after privatization, $K$ factors were mostly set quite generously in order to allow the companies sufficient funds for a back-log of capital investment.

At privatization, environmental regulation of the aquatic environment, previously done by the public water authorities, was now separated from the new private water companies. The main environmental regulator in the UK is now the Environment Agency (EA). It has the authority to initiate prosecution of companies, and all water companies have been prosecuted at various times since privatization, mostly for breaches of discharge consents (Bakker, 2003; information from respondents). The EA generally seemed to favour a co-operative approach, rather than a confrontational one, and compliance was often negotiated with companies rather than strictly enforced (cf. Fineman, I998).

The Office of Water Services (OFWAT), the Environment Agency (EA) and the water companies are the key players in a dynamic and often conflictive regulatory field, engaged in shifting coalitions and often complex game playing (Maloney, 200I). OFWAT and the EA often show divergent interests and motives. They favour different regulatory modes - the EA favours enforcement compliance while OFWAT tends towards negotiated compliance - and have divergent regulatory objectives with respect to trade-offs between cost and environmental improvement. In the price review of I999, OFWAT reduced industry estimates of the costs for implementing the EU Urban Waste Water Directive by nearly 30\%, resulting in what the industry described as a very tough price review (interview responses). This action was thought to reflect some of the public disquiet over high profit margins in the industry. However, pricing levels were allowed to rise again in the following years up to the present day (OFWAT, 2006). 
The regulatory field in the water industry is characterized by shifting coalitions of actors. OFWAT and consumer groups may be in coalition to keep prices down, the Environment Agency and environmental pressure groups may join forces to argue for stricter environmental standards and the EA and the water companies may be in coalition to argue for more environmental investment and hence a higher $K$ factor. The regulatory field of the UK water industry is thus characterized by a high degree of instability and fluidity, availability for occupation by different actors, lively contests and oscillation between periods of conflict and consensus. This is a regulatory regime with institutionalized conflict built in, reflecting different values of the main regulatory bodies (Maloney, 200I).

\section{Methodology}

Data for this paper was collected through a qualitative study with managers in three companies in the UK water companies. It is part of a larger study looking at environmental strategy and management in these companies. Regulatory issues were one aspect of several in this wider study. The water industry was chosen for this study for several reasons: it has significant, direct environmental impacts and is subject to heavy environmental regulation; it is also subject to significant economic regulation; privatization provided an opportunity for a previously very homogenous industry to diversify and for companies to develop their own strategic direction. These characteristics combine to make the industry an ideal case for the study of the interacting effects of economic regulation, environmental regulation and company strategy on corporate environmental strategy and management.

For reasons of confidentiality, it has been agreed not to name the companies or individual respondents. Data was collected over two periods - I996/97 and 2000/OI. In the first research period 24 interviews were conducted and in the second research period I6 managers were interviewed (see Appendix I). Much of the data used for this paper comes from the second phase of the research, as this took place after the particular regulatory event studied, i.e. the third price review in I999. Data from the first phase of the research is used to show how respondents' views of the industry's relationship with both OFWAT and the EA developed over the period of the research.

The three companies in the study show some differences in structure; for instance, Companies A and B are UK owned and Company $\mathrm{C}$ is owned by a large multi-national water utility. All three companies have international business interests and are actively pursuing further international expansion. They have also diversified to some extent within the UK markets, into areas such as electricity distribution, waste management and services management. However, they are fairly comparable in most aspects of their core water and sewerage business, such as the main technical aspects of managing water supply and waste water treatment, and the market structure in which they operate, where they have regional monopolies for domestic customers but are faced by limited competition in industrial and commercial markets.

The main form of data collection consisted of a series of semi-structured interviews, where the researcher asked fairly open-ended questions on a set of topics developed from the literature, including overall company strategy, environmental strategy and attitudes towards environmental management, and relationships with economic and environmental regulators (as well as other stakeholders). Outline interview schedules for both phases are given in Appendix II. The topics given in Appendix II were covered in all interviews but sometimes not in this order, when respondents chose to bring up a later topic earlier of their own accord. At the same time, respondents were given the opportunity to explore issues that were of importance to them. This was done both implicitly, by allowing them to develop divergent themes in response to questions, and by asking explicitly for further issues at the end of the interview. In the second research phase much of the material on the third price review by OFWAT was brought up by respondents themselves without probing, indicating that this was a topic of importance to them at that point in time.

The interviews lasted between 45 and 90 minutes and were mostly tape recorded and later transcribed. Where tape recording was not possible, extensive notes were taken during and immediately following the interview. Many of the references to regulation made by respondents were unprompted or only elicited through fairly general questions regarding the importance of difference 'drivers' of environmental strategy.

I This first period of research was funded by the Economic and Social Research Council of the UK under its Global Environmental Change Programme, Grant No. L 32I 253209. 
Analysis was interpretative, with an emphasis on the meanings that respondents attached to events and on uncovering both convergent and divergent interpretations and responses to the regulatory field. The analysis followed an iterative pattern, where the broad research question, relating to the impact of regulation in general and economic regulation in particular on environmental management, was derived from the literature. More detailed categories of analysis, relating to the specific responses to the 1999 price review, were derived from initial data analysis in a grounded, bottom up approach. These categories were then employed for more systematic within and between case comparisons.

\section{Environmental Management and Regulatory Changes - Empirical Findings}

The aim of this empirical investigation was to uncover how managers in the industry construct and respond to the regulatory field and changes within it. It concentrates on one particular regulatory episode: the third price review by the economic regulator, OFWAT. This price review tightened the prices that companies were allowed to charge their customers temporarily and was described by several respondents as 'tough'. It presents an opportunity to investigate what happens to environmental commitment in a situation where the financial situation of a company becomes tighter. In this respect, the findings may contribute to our understanding of the relationship between firms' environmental and economic performance. As these companies are also subject to significant environmental regulation, this case also presents an opportunity to study the interaction of somewhat contrary regulatory demands from two different regulators and firms' response to this potential conflict.

From the literature review we may expect that changes in economic regulation that affect firms' financial situation will have an impact on their environmental engagement and that this impact may vary depending on firms' strategic outlook and particularly their views of the relationship between environmental engagement and financial performance. As some aspects of environmental engagement are mandated by environmental regulation and thus not optional for firms, we may also expect that their response to changed economic regulation will be different for regulated and non-regulated environmental engagement. In addition to these, two further categories of firm response to the regulatory review emerged from the interviews. Not surprisingly, firms also responded in commercial terms, which are not directly the focus of this paper, but an understanding of which helps to put the environmental responses into context. A fourth category relates to tactical responses, which might be termed 'playing the regulatory game. These four categories are discussed in turn in the remainder of this section.

\section{Commercial Responses to a 'Tough' Regulatory Review}

The water industry in the UK had gone through four regulatory reviews since privatization. The first one was set immediately after privatization, the second one in 1994 and the third one in I999. The fourth regulatory review period started in 2004. This paper focuses on the third regulatory review, which translates into Asset Management Plan 3 (AMP3). It was the most recent at the time of research and encompassed an important perceived change in emphasis by the regulator, demanding more attention to cost and lower prices than previous reviews had done. The following extract from an OFWAT press release illustrates this thinking:

WATER PRICES TO FALL BY I4\% NOW - AND STAY DOWN Customers can see lower bills - for the first time since privatisation - as well as better services and a major programme of environmental improvements. This is largely thanks to the growing efficiency of the water companies. The regulator, Ian Byatt, Director General of Water Services, is now making sure that the benefits are passed on to customers (OFWAT, I999).

This 'tough' price review was highly salient to the respondents at that particularly period and often referred to without prompting. Nearly all respondents, in all three companies agreed that, as a result, less money was available and cost saving had become a more prominent feature of business in their companies. The following quote stands for many similar ones. 
A lot of the water companies are very, very concerned about cash, and if you look at our [predicted profits] for the next five years it looks pretty, pretty desperate.... All of those things are going in the wrong direction. And that's true for the whole of the water industry. Whereas at some point it was an absolute cash cow and you could borrow large amounts of money very easily, that's getting more difficult, too (Respondent 9, Company C).

While respondents in the second research phase felt quite strongly that the I999 price review had been particularly 'tough', it is worth pointing out that many respondents in the first research phase voiced similar sentiments that OFWAT was squeezing prices and thus jeopardizing companies' sound finances and environmental investment (although respondents brought up the topic less frequently and with less emphasis in the first phase). The following quote illustrates this:

There is more and more pressure from the regulator to squeeze costs more and more, less and less room to explore some of the [wider environmental] issues (Respondent I, Company C).

However, this does not invalidate the fact that many respondents in the second research phase felt that their companies were currently under particular financial pressure.

One type of response to the third price review in I999 emerging from the interviews was a commercial one. Although commercial responses to changes in economic regulation are not the main focus of this paper they are important to the understanding of firms' responses to regulation as a whole and interact with responses in terms of environmental engagement. Two, mutually compatible, commercial responses were presented. On the one hand, managers in all three companies reported an increased emphasis on cost savings, which was perhaps expressed in the most pronounced manner in Company B, where the appointment of a new managing director, who was reported to be highly focused on efficiency and cost savings, and two restructurings, involving a reduction in staffing levels, coincided.

These new structures were agreed in October and ... [then] there was a new Managing Director of [our divis ion] ... [and] he's immediately launched a fresh restructuring, which has been very fundamental in that it involved everybody applying for their own jobs ... There are quite a number of people going on voluntary severance.... After the last periodic review was announced, it was a very tough review, we've got to make major savings, so that was the purpose of this restructuring. Then, when [the new MD] arrived and it was announced that he was going to increase the savings by another I5 million, that's over the five year period, but it is really driven by this incredibly tough regulatory review, where we have to invest more and cost less. And clearly that is an extremely tough job (Respondent II, Company B).

Respondents in Company B emphasized cost savings most but the theme ran through all three companies. Another commercial strategy, reinforced by the price review, was to diversify away from the domestic, regulated utility side. All three companies had been pursuing international expansion in water and sewerage and domestic diversification into related industries for some years, in order to expand and to maintain profit levels, which was difficult in the domestic water market. The most recent price review was cited as a further reason to pursue these strategies.

These commercial responses can be seen to interact with environmental responses. A cost saving strategy may normally be expected to lead to reduced discretionary (and possibly also mandated) environmental expenditure, unless such expenditure is seen as making a contribution to increased earnings or as reducing other costs, as has been suggested in win-win arguments (e.g. Elkington, I994; Porter and van der Linde, I995). On the other hand, a diversification strategy may have different impacts on discretionary environmental expenditure, depending on whether the company considered good environmental reputation to bring competitive advantage in the markets into which it is diversifying. 


\section{Environmental Engagement Covered by Legislation}

Much of the environment related activity of water companies in the UK is mandated by environmental legislation, most of it emanating from the European Union. One of the proposed reasons for privatization of the industry was to find a way to fund companies to be able to meet these legal requirement, which the UK water industry, thought to be suffering from decades of underinvestment, had not done previously (Bakker, 2003). The water industry regulator, OFWAT, has an obligation to ensure that water companies have sufficient funds to carry out their legal obligations. This is acknowledged in their mission statement (albeit only briefly in a statement that focuses on customer services and value):

Following the Water Act 2003, our duties were extended to include a duty to 'exercise and perform powers and duties ... in the manner ... best calculated to contribute to the achievement of sustainable development' (http://www.ofwat.gov.uk/aptrix/ofwat/publish.nsf/Content/sustainable_development).

The I999 regulatory review had allowed for further capital investment to meet water quality and environmental legislation, although the companies had been allowed less money to carry out these investments. Managers in all companies stressed that the price review had not affected investment into asset upgrading designed to meet EU legislation. However, they felt their companies had to make greater cost savings in order to be able to run a profit.

At least the funding is there in the programme, although our funding is a lot less than our estimates of how much it was going to cost, and that's why things are very tough around here at the moment. But it is getting done and, as usual when you have a kind of siege economy, when you're told you've only got a very small resource, you do actually get more ingenious in the way you solve the problem. And I think they will continue, amazingly, to deliver savings on these large amounts ... the opportunity to do so many overflows all at once gives you the opportunity ... to create synergies in the way you handle the solutions (Respondent II, Company B).

As most environmental activity and investment in the water industry is currently mandated by legislation, the price review was thus seen as having relatively little effect on many of the physical improvements being made.

\section{Discretionary Environmental Activities}

While mandated environmental investment (funding for which was agreed with OFWAT) would not be expected to suffer directly from a perception that less money was available, the general importance given to environmental engagement and discretionary expenditure in this field can be expected to be affected. Many respondents suggested that a greater emphasis on cost savings had an effect on discretionary environmental activities. As the discussion above about the role of company strategy and views on the relationship between economic and environmental performance would lead us to expect, it was in this area that differences between the responses in different companies became more obvious.

The most concerned respondents were found in Company B. One senior manager insisted that the company was taking environmental issues very seriously, and that the company engaged with both mandated and voluntary environmental activities, although voluntary activity needed to be related to the company's overall strategy and, ultimately, provide a business benefit. Other, less senior managers in the same company were much less genuine about the company's overall commitment to non-mandatory environmental activity and the standing of environmental concerns in general in the company. There were concerns that the company's current emphasis on cost savings - to adapt to the terms of the latest price review - had led to reduced budgets and staffing levels, making non-mandated and even some mandated environmental activities harder to carry out.

Unless I'm quick enough on my feet to demonstrate what the underlying business benefits of those things are they will be cut quite ruthlessly. ... I think at the moment the focus of the business is getting it into lean and mean and efficient, and I've got to be very careful to keep this on the agenda in the right way (Respondent II, Company B). 
There were some concerns that environmental issues had slipped down the company's agenda and that this might eventually lead to non-compliance with environmental regulation in some areas.

... certain criteria, which are obligations, statutory obligations but not necessarily going to hit you hard financially, the softer issues have been not afforded the due time, effort and concern (Respondent I2, Company B).

There was a feeling in Company B that top management commitment to environmental issues had always been a bit changeable but in the previous research phase it had generally been felt to be quite good, as the following quote illustrates:

I think you have got commitment right at the top, and that is actually ... it is the fact that we have got him now, rather than the previous chief executive, who actually consciously blocked. . . But I do believe we've now got that support right from the top, yes we do. . . my [immediate] boss has always been in favour of it (Respondent 4, Company B).

Respondents in Company $\mathrm{C}$ were concerned that environmental management in the company was driven mostly by legislative requirements and that wider environmental issues were not very high on the agenda. This was less strongly linked to the recent price review than in Company B but was presented as always having been the case (including in the first research period).

I'd say we are very good at compliance driven issues, water efficiency, sewage treatment, sludge, we have a good handle on what's happening with that... We're not so good on the non-compliance issues, I'd say ... There still needs to be sustainable development put through into mindsets and decision making, it's not there at the moment (Respondent Io, Company C).

Unlike in Company B, there was no suggestion in Company $\mathrm{C}$ that mandatory environmental issues were suffering, even at the margins.

Respondents in Company A felt that commitment to good environmental performance, and even environmental leadership, at the top and throughout the company was sufficient to make sure discretionary environmental activities were not entirely marginalized, but the regulatory review had made it more difficult to find the time and resources to attend these issues.

Because of the price cuts imposed on us by the regulators we had to make redundant about $20 \%$ of our staff and the organization is now very, very stretched. So, despite the continuing commitment to environmental and community issues there is now less headroom to do these things. Our CEO remains very committed but there is a dilemma in making redundant good people who were doing good, useful work in the organization because you end up in a situation where you either put more pressure on the remaining staff or you have to axe some activities, for instance the educational work we do. For the moment we have decided to stick with the educational programme but it does put more pressure on people and more staff losses would not be sustainable (Respondent 8, Company A).

This section shows somewhat different (perceived) responses from the three companies in terms of non-mandatory environmental engagement, which may in part be attributable to different strategic outlooks. Company A was positioning itself in terms of 'environmental leadership' much more explicitly than the other two companies (although this did not, in the eyes of managers from Companies B and C, necessarily mean that Company A's measurable environmental performance was better). Respondents in Company A expressed a belief that a good environmental reputation was beneficial in securing contracts in competitive (industrial or international) markets, as illustrated by the following quote: 
Environmental issues play a role in our business-to-business market. Most big companies are developing their own environmental responsibility programme and so they rely on their contractors to achieve their goals ... (Respondent 8, Company A).

Top management commitment in Company A, mentioned in the previous quote, may plausibly be attributed to this perceived customer demand and environmental positioning.

The other two companies had not made quite the same public statements about positioning themselves as environmental leaders. Some respondents in Companies B and C expressed the view that, due to the stretch in resources imposed by the $\mathrm{AMP}_{3}$ regulatory review, environmental performance and hence reputation might be threatened.

We're desperately trying to think how to keep our domestic customers on board, and interestingly enough, one of the areas where all the brand analysis says that we're very strong is actually environment. ... [Our company name] still is a very good environmental brand. [But we are] having a credibility stretch at the moment, something very dramatic I think (Respondent 9, Company C).

Respondents in Company B also felt that the current efficiency drives were jeopardizing the positive environmental image that the company had. One manager suggested that an insufficient realization of the strategic and competitive benefits of good environmental performance was partly to blame for decreased attention to this area.

These findings would suggest that a company's beliefs about the impact of environmental performance on competitive advantage may indeed influence their environmental response to tighter economic circumstances.

\section{Playing the Regulatory Game}

A fourth analytical theme emerged from the interviews and is called 'playing the regulatory game' here, as it involves alliances between different organizations in order to gain mutual benefits from the regulatory system. There is an obvious advantage for the water companies in being allowed higher prices by OFWAT. High capital investment requirements for improved environmental standards have been the main reason why price increases had been allowed in the past (and were continuing to be allowed, albeit not at the same level), and this had contributed directly to the good financial performance of the companies (Bakker, 2003; Maloney, 200I). Environmental organizations and the environmental regulator also have an interest in the water companies being allowed funds to invest in environmental improvements. These organizations and the water companies have therefore been in alliance in trying to persuade OFWAT to allow fairly generous environmental investment levels. This is notwithstanding the fact that some respondents also pointed out that the Environment Agency seemed to have become less lenient with them over recent years, the result they felt, of a mixture of personal and policy factors at the EA.

Despite this, the Environment Agency and environmental NGOs were seen as potentially valuable allies in persuading OFWAT of the need for further environmental investment.

That's what was interesting about $\mathrm{AMP}_{3}$. For the first time ever the debate around the environment was not us versus [the environmental regulators] but us and the EA against OFWAT. Which was totally different from what it previously was (Respondent 9, Company C).

As well as through alliances at a more general level, the companies played the regulatory game at a very detailed level, revolving around individual emission consents and investment in individual sewage treatment plants. One example is a situation where Company B had invested in treatment facilities that resulted in better environmental performance than that required by the consent for that treatment works. The environment manager explained why this high standard was maintained and how the company was trying to use it to its advantage in its negotiations with OFWAT and the EA. 
We are smashing the consent.... So we could actually ease off on the energy going into that plant, or we could put a bit less effluent through it and blend again to meet that consent more tightly, to give us some room for manoeuvre and legally we'd still be fine. But obviously that would have a direct knock-on impact on the river system as a result.... these are actions that ... are costing us money but are having a direct benefit for the environment. What we're really trying to do, in that particular case, is to work with the [Environment] Agency to commission a study of the [waterway], and the recommendations of that would be that the improvements that we are doing voluntarily [there], and other work that we haven't yet started, ... shou ld be made statutory. And saying to the Agency 'you should tighten that consent up and [we] should then be allowed the extra revenue that we're spending voluntarily'. If that comes off it would have been a good example of how doing the right thing eventually comes back and works in your favour (Respondent II, Company B).

Both environmental and economic regulation are thus evidently not treated as a given by the firms. Rather, they are using collaborative behaviour in order to influence the regulatory outcome.

Apart from the fairly direct financial benefit of more funding for environmental investment, respondents also explained that good environmental performance was important to them in terms of public goodwill and in terms of gaining and retaining customers in the light of more competitive threats (already briefly discussed in the previous section). A good public image can be seen as a further element in the regulatory game. After privatization, the water industry suffered from a number of problems in terms of its public image. Privatization was unpopular among a high proportion of the population and increased water charges paired with the perception of abnormally high profits and 'fat cat' salaries for top executives caused much negative publicity, which then became a political issue. The stricter third regulatory review had been partly attributed to political pressure caused by this negative public perception (Maloney, 200I). Respondents expressed the hope that good environmental performance would lead to a better public image and that a better public image would reduce the pressure on OFWAT to be seen to be tough with the water industry by imposing further stringent price reviews. It is interesting to note that OFWAT also uses environmental (as well as customer service) arguments to justify continuing rises in water prices:

We set price limits that are as high as they need to be, but no higher. They will allow water companies to meet your needs and the needs of the environment while continuing to deliver a safe and reliable service (http://www. ofwat.gov.uk/aptrix/ofwat/publish.nsf/Content/protecting_interests280905).

\section{Conclusion}

The case studies analysed in this paper, as well as some of the previous literature, show a complex regulatory field, where not only environmental regulators but also, crucially, the economic regulator have a highly significant impact on environmental actions within the UK water industry, and where environmental goals and economic regulation are intricately bound up with each other.

The specific circumstances found in this research are, to some extent, particular to the UK water industry. However, some generalizations about them may be drawn from the findings presented here. First, the findings suggest that, in addition to the impact of environmental regulation on environmental performance (cf. Hunt and Raman, 2000; King, 2000) and on economic performance (cf. Wubben, I999; Jaffe et al., I995), economic regulation has some impact on environmental engagement of firms, via its impact on available income.

Second, economic and environmental regulation interact in their impact on environmental engagement. As the economic regulator has a legal obligation to safeguard sustainable development of the UK water industry, mandated environmental engagement in the firms was not directly impacted by a tighter price review. However, non-mandatory environmental engagement was seen to be under more threat in a situation where the third price review by OFWAT had introduced greater emphasis on efficiency gains and hence a greater emphasis on cost savings in the companies. This was felt in all three companies to some extent and suggests that such discretionary environmental activities were not necessarily seen as contributing to short term competitive advantage (cf. Wubben, I999). 
This leaves a somewhat mixed picture regarding the relationship between economic and environmental pressures and performance, which - although looking at a somewhat different link between the two - is not out of line with the overall tenor of research into the relationship between CSR and economic performance (cf. Margolis and Walsh, 2003; Pava and Krausz, I996).

Third, this response in terms of non-mandatory environmental engagement seemed tempered by a company's strategic outlook. In Company A, which had adopted an explicit environmental positioning strategy, respondents reported fewer immediate concerns over the maintenance of discretionary environmentally related projects, although they also acknowledged the pressure from the 1999 price review. The current research thus seem to lend some further support to previous research that suggests that the strategic outlook of a firm will influence its response to economic and environmental regulation (cf. Søgaard and Madsen, 2005; Rugman and Verbeke, 2000).

Fourth, firms responded to regulatory pressures not just individually and as a given, but engaged in (informal) alliances with other players in the regulatory field (e.g. the Environment Agency) in order to achieve more favourable economic regulatory outcomes both at a general and at a detailed level. This would seem to confirm notions that regulation is a flexible process, negotiated through repeated interactions between the regulator and the regulated (cf. Fineman, I998; Fineman and Sturdy, I999) and that, depending on the institutional and economic context, possible responses to regulation include collaborative behaviour (cf. Harrison and Easton, 2002).

Finally, we may conclude that the interrelationships between different types of regulation, industry and the environment can be highly complex, and changes in one area cannot be seen in isolation from changes in the other areas. 


\section{Appendix I}

Company A

7

No of

interviews

at Stage 2

Respondents

2 at Stage

1. Environmental director ( $=$ No. 8 below

2. Environmental manager

3. Environmental co-ordinator (= No. 9 below

4. Area sewage treatment management ( $=$ No. 12 below

5. Regional sales manager

6. Facilities manager

7. Water supply and conservation officer

8. Environment director (= No. 1 above)

9. Environmental co-ordinator (= No. 3 above)

10. Water supply director

11. Environment director

12. Area sewage manager (= No. 4 above)

13. Conservation, access and recreation advisor 14. Information manager
Company B

9

1. Group technical director

2. Group health, safety \& environment manager

3. Group environmental advisor

4. Environment manager (= No. 11 below),

5. Waste compliance officer (= \#13 below)

6. Conservation, access $\&$ recreation manager (= No. 12 below)

7. Waste water general manager

8. Waste management officer

9. Water supply manager

4

5

10. Group strategic planning director

11. Environment manager (= No. 4 above)

12. Conservation, access $\&$ recreation manager (= No. 6 above)

13. Environmental compliance manager (= \#5 above)
Company C

8
1. Environmental director

2. Environmental management systems manager

3. Conservation manager (= No. 9 below)

4. Regional production manager

5. Technical support officer, sewerage

6. Regional estates manager

7. Technical controls manager

8. Director, environmental consultancy division
9. Environment manager (= No. 3 above)

10. Environmental communications manager

11. Asset manager

12. R\&D manager

13. Regional environmental co-ordinator

\section{Appendix II}

\section{Outline Interview Schedule for Phase I}

I. Company structure and environmental responsibility

2. Respondent's own role

3. Key environmental impacts

4. Importance of environmental issues and top management commitment 
5. Is environment a strategic issue?

6. Benefits of good environmental performance

7. Development and function of environmental policy and environmental management system (where applicable)

8. Collection and reporting of environmental information

9. Key environmental stakeholders and company's relations with them - probing questions about particular stakeholders, including environmental and economic regulators

Io.Training and other HRM measures to aid environmental management

II. Environmental issues in customer relations and procurement.

\section{Additional Questions for Phase II}

12. Structural and strategic changes since the first research phase

I3. Changes in key environmental impacts

I4. Changes in importance given to environmental issues and top management commitment

15. Key environmental stakeholders now and company's relationship with them.

\section{References}

Bakker K. 2003. An Uncooperative Commodity: Privatizing Water in England and Wales. Oxford University Press: Oxford.

Crane A, Matten D. 2004. Business Ethics. Oxford University Press: Oxford.

Eden S. I997. Regulation, self-regulation and environmental consensus: lessons from the UK packaging waste experience. Business Strategy and the Environment 6(4): 232-24I.

Elkington J. I994. Towards the sustainable corporation: win-win-win business strategies for sustainable development. California Management Review Winter: 90-100.

Fineman S. 1998. Street level bureaucrats and the social construction of environmental control. Organization Studies I9(6): 953-974.

Fineman S, Sturdy S. I999. The emotions of control: a qualitative exploration of environmental regulation. Human Relations 52(5): 63I-663.

Harrison D, Easton G. 2002. Collective action in the face of international environmental regulation. Business Strategy and the Environment II(3): I43-I53.

Hunt CB, Auster E. I990. Proactive environmental management: avoiding the toxic trap. Sloan Management Review 3I(2): 7-I8.

Hunt J, Raman S. 2000. Regulation matters: global environmental discourse and business response. In The Business of Greening, Fineman S (ed.). Routledge: London; II4-I33.

Jaffe AB, Peterson SR, Portnoy PR, Stavins RN. I995. Environmental legislation and the competitiveness of U.S. manufacturing: what does the evidence tell us? Journal of Economic Literature 33(I): I32-163.

King A. 2000. Organizational response to environmental regulation: punctuated change or autogenesis? Business Strategy and the Environment 9(4): 224-238.

Low P, Yeats A. I992. Do dirty industries migrate? In International Trade and the Environment (World Bank Discussion Papers 159), Low P (ed.). World Bank: Washington, DC; 89-IO3.

Maloney WA. 200I. Regulation in an episodic policy-making environment: the water industry in England and Wales. Public Administration 79(3): 625-642.

Maltby J. I997. Setting its own standards and meeting those standards: voluntarism versus regulation in environmental reporting. Business Strategy and the Environment 6(2): 83-92.

Margolis JD, Walsh JP. 2003. Misery loves companies: rethinking social initiatives by companies. Administrative Science Quarterly 48: 268305.

McWilliams A, Siegel D. 2000. Corporate social responsibility and financial performance: correlation or misspecification? Strategic Management Journal 2r: 603-609.

OFWAT. I999. Water Prices to Fall by 14\% Now - and Stay Down, OFWAT press release 27 July I999. http://www.gnn.gov.uk/Content/Detail. asp?ReleaseID=2785 I\&NewsAreaID=2 [2 March 2007].

OFWAT. 2006. OFWAT Summarises Water Bill Increases. http://www.ofwat.org.uk [20 April 2006].

Parker D. I997. The regulation of privatised utilities: reflections on the UK experience. Review of Policy Issues 3(3): 3-37.

Pava ML, Krausz J. I996. The association between corporate social-responsibility and financial performance: the paradox of social cost. Journal of Business Ethics I5: 32I-357.

Pickman HA. I998. The effect of environmental regulation on environmental innovation. Business Strategy and the Environment 8(3): I89I96.

Porter M, van der Linde C. I995. Green and competitive: ending the stalemate. Harvard Business Review 73(5): I20-I33.

Roome N. I992. Developing environmental management strategies. Business Strategy and the Environment 3(4): 9-16. 
Rugman AN, Verbeke A. 2000. Six cases of corporate strategic responses to environmental regulation. European Management Journal I8(4): $377-385$.

Schaefer A, Harvey B. 2000. Agents of change in corporate greening: case studies in water and electricity utilities. In The Business of Greening, Fineman S (ed.). Routledge: London; 169-188.

Smith A. 1996. Voluntary schemes and the need for statutory regulation: the case for integrated pollution control. Business Strategy and the Environment 5(2): 8I-86.

Smith M, Crotty J. 2006. Environmental regulation and innovation driving ecological design in the UK automotive industry. Business Strategy and the Environment. www.interscience.wiley.com [20 February 2007]. DOI: I0.1002/bse.550

Søgaard V, Madsen SO. 2005. The red queen and the environment: reconciling public regulation and business strategy. Business Strategy and the Environment. www.interscience.wiley.com. [20 February 2007]. DOI: I0.I002/bse.486

Stead WE, Stead JG. I996. Management for a Small Planet, 2nd edn. Sage: Thousand Oaks, CA.

Thatcher M. I998. Institutions, regulation and change: new regulatory agencies in British privatised utilities. West European Politics 2I(I): I20-I47.

Wubben E. I999. What's in it for us? Or: the impact of environmental legislation on competitiveness. Business Strategy and the Environment 8: 95-107. 